\title{
Het toepassingsbereik van de klachtplicht
}

\author{
$M r . J . J . V a l k^{*}$
}

\section{Inleiding}

De klachtplicht van art. 6:89 BW heeft betrekking op gebrekkige prestaties, dat wil zeggen prestaties van een schuldenaar die niet aan de verbintenis beantwoorden. De klachtplicht ziet derhalve niet op een vordering uit onrechtmatige daad. ${ }^{1}$ Met dit oordeel beslechtte de Hoge Raad vorig jaar een netelige kwestie waarover verschillend werd gedacht: geldt de klachtplicht ook bij een zuivere onrechtmatige daad? ${ }^{2}$

Ik noem de kwestie netelig omdat de klachtplicht als nogal 'schuldenaarsvriendelijk' wordt ervaren. ${ }^{3}$ Toepassing bij onrechtmatige daad zou dus in het voordeel van de laedens kunnen zijn uitgepakt. Het probleem van de klachtplicht is de ongenuanceerde sanctie van te laat klagen: de schuldeiser verliest alle rechtsvorderingen en verweren ter zake van het gebrek. Dit aanlokkelijke perspectief voor schuldenaren heeft ertoe geleid dat zij, sinds de 'ontdekking' van de klachtplicht ruim tien jaar geleden, zich te pas en te onpas op de klachtplicht beroepen. Vaak valt immers best te verdedigen dat de schuldeiser eerder had kunnen klagen dan hij heeft gedaan. De Hoge Raad heeft het afgelopen decennium geprobeerd het evenwicht tussen schuldeiser en schuldenaar te herstellen. Zo zal een beroep op de klachtplicht niet snel slagen als de schuldenaar door het late tijdstip van de klacht niet in zijn belangen is geschaad. ${ }^{4}$ Vranken signaleert echter terecht dat de echte boosdoener, de sanctie, nooit is aangepakt. ${ }^{5}$

Mr. J.J. Valk is advocaat bij De Brauw Blackstone Westbroek te Amsterdam en redacteur van dit tijdschrift.

1. HR 13 juli 2018, ECLI:NL:HR:2018:1176, r.o. 3.6.

2. Bevestigend: E.A.L. van Emden \& M. de Haan, Klachtplicht ook bij (zuivere) onrechtmatige daad?, AV\&S 2013/11, afl. 3, p. 91-95. Neigend naar bevestigende beantwoording: W.H. van Boom, annotatie bij HR 8 februari 2013, ECLI:NL:HR:2013:BY4600, AA 2013, p. 759 (Van de Steeg/Rabobank). Ontkennend onder anderen: Asser/Sieburgh 6-I 2016/408e; J.L. Smeehuijzen, Hoe het verjaringsrecht door de klachtplicht wordt opgegeten - en waarom dat erg is, WPNR 2013, afl. 6988, p. 743-744.

3. Zie bijv. J.B.M. Vranken, De facelift van een oude dame. Verborgen gebreken en klachtplichten, WPNR 2019, afl. 7231, p. 225-226; Asser/ Hijma 7-I 2019/800: 'Nogal wat schrijvers menen - met recht - dat de klachtplichtbepaling het gevaar in zich bergt dat de verkoper te snel in veilige haven geraakt, ten koste van de koper, jegens wie hij toch is tekortgeschoten.'

4. HR 8 februari 2013, ECLI:NL:HR:2013:BY4600 (Van de Steeg/Rabobank), r.o. 4.2.4, 4.2 .6 en 4.3.4.

5. Vranken 2019, p. 226
Deze onevenwichtigheid maakt het toepassingsbereik van de klachtplicht een dankbaar voorwerp van debat. Geldt de klachtplicht bijvoorbeeld bij de betaling van een geldsom? ${ }^{6}$ Is de klachtplicht van toepassing op interne bestuurdersaansprakelijkheid (art. 2:9 BW) ? ${ }^{7}$ En moet een werknemer tijdig klagen over de schending van de zorgplicht door zijn werkgever voor, kort gezegd, een veilige werkplek (art. 7:658 lid 1 BW)? ${ }^{8}$

6. Bevestigend: F.M. van Cassel-van Zeeland, De klachtplicht bij een gebrekkige betaling van geld, AA 2019, p. 282-287; A.J.P. Schild, De klachtplicht en bestuurdersaansprakelijkheid, bien étonnés de se trouver ensemble?, in: E.B. Rank-Berenschot e.a. (red.), Alles afgewogen: privaatrechtelijke opstellen aangeboden aan mr. C.L. de Vries LentschKostense ter gelegenheid van haar afscheid als Plaatsvervangend Procureur-Generaal bij de Hoge Raad der Nederlanden, Deventer: Wolters Kluwer 2016, p. 64; T.S. Jansen, Rechtsverwerking naar omstandigheden, TOP 2013, p. 169-170; B.M. Katan, De ondergrens van artikel 6:89 BW, Contracteren 2007, p. 47. Ontkennend: A-G Wissink in zijn conclusie voor HR 2 september 2011, ECLI:NL:PHR:2011:BQ3876, NJ 2012/75 m.nt. P. van Schilfgaarde (VDE/Fuchs), nr. 2.50.7; Asser/ Hijma 7-I 2019/848; R.P.J.L. Tjittes, Rechtsverwerking en klachtplichten (Mon. BW nr. A6b), Deventer: Kluwer 2013/30. De lagere rechtspraak laat een wisselend beeld zien; zie Van Cassel-van Zeeland 2019, noot 16 en I.L. Gerrits \& M. Opdam, De klachtplicht in het arbeidsrecht, ArbeidsRecht 2017/32, afl. 6/7, p. 17-20.

7. Zie bijv. S.A.L.L. Caris \& D.J.M. Kulk, Interne bestuurdersaansprakelijkheid en de klachtplicht: de uitzondering op de regel of de regel op de uitzondering?, $\mathrm{MvO} 2018$, p. 249-256 (klachtplicht van toepassing); M.J. Kroeze, Klachtplicht en bestuurdersaansprakelijkheid, RMThemis 2015, p. 185-186 (klachtplicht van toepassing naar de letter van de wet, maar dat is onwenselijk); A.J. Rijsterborgh \& Z.D. Veldhoen, De onwenselijkheid van de toepassing van de klachtplicht uit art. 6:89 BW op vorderingen ex art. 2:9 BW: een dogmatisch en praktisch perspectief, MvV 2015, p. 99-105 (klachtplicht niet van toepassing); Schild 2016, p. 63-64 (klachtplicht niet van toepassing); R.P.J.L. Tjittes, Een klachtplicht bij interne bestuurdersaansprakelijkheid?, in: G. van Solinge e.a. (red.), Aansprakelijkheid van bestuurders en commissarissen. Nadere terreinverkenning van een uitdijend rechtsgebied, Deventer: Wolters Kluwer 2017, p. 473-488 (klachtplicht niet van toepassing); J.B. Huizink, Bij bestuurdersaansprakelijkheid hoort geen klachtplicht, O\&F 2018 , afl. 3, p. 5-13 (klachtplicht niet van toepassing). De lagere rechtspraak laat een wisselend beeld zien: Rb. Midden-Nederland 19 juni 2013, ECLI:NL:RBMNE:2013:CA3225, r.o. 6.8 (klachtplicht van toepassing); Rb. Zeeland-West-Brabant 5 november 2014, ECLI:NL: RBZWB:2014:9203, r.o. 3.11-3.16 (klachtplicht niet van toepassing); Rb. Midden-Nederland 3 december 2014, ECLI:NL:RBMNE: 2014:6198, r.o. 4.9 (klachtplicht van toepassing); Rb. Zeeland-WestBrabant 14 september 2016, ECLI:NL:RBZWB:2016:5790, r.o. 3.5.5 (klachtplicht niet van toepassing, tenzij vordering feitelijk gegrond op niet-nakoming arbeidsovereenkomst bestuurder); Hof Arnhem-Leeuwarden 24 januari 2017, ECLI:NL:GHARL:2017:523, r.o. 5.14 (klachtplicht niet van toepassing).

8. Onder meer over deze vraag: Gerrits \& Opdam 2017. In de lagere rechtspraak tekent zich een meerderheid af vóór toepassing van de klachtplicht op de zorgplicht van de werkgever. 


\section{Maandblad}

De praktijk worstelt met deze vragen, die de Hoge Raad nog niet heeft beantwoord. De vraag naar het toepassingsbereik van de klachtplicht is, aldus Vranken, nog 'volop in beweging. ${ }^{9}$

Het debat over het toepassingsbereik van de klachtplicht wordt vaak gevoerd vanuit twee perspectieven: wat zegt de wetsgeschiedenis, en wat volgt uit de ratio van de klachtplicht? In mijn ogen heeft echter geen van deze perspectieven een overtuigend antwoord opgeleverd. Integendeel, de praktijk wijst uit dat rechtsgeleerde schrijvers met een beroep op bijvoorbeeld de ratio van de klachtplicht tot tegengestelde conclusies komen (zie par. 3.2).

Dat is voor mij reden om in dit artikel een rechtssystematische benadering te beproeven. Welk toepassingsbereik sluit aan bij het systeem? Ik ben mij ervan bewust dat ook deze benadering haar beperkingen heeft en op zich niet doorslaggevend kan zijn. ${ }^{10}$ Maar ze levert volgens mij wel nuttige inzichten op. De Hoge Raad heeft het toepassingsbereik van de klachtplicht namelijk opgehangen aan twee klassieke rechtsbegrippen: de klachtplicht is van toepassing op alle 'verbintenissen'11 en heeft slechts betrekking op 'gebrekkige prestaties'. ${ }^{12}$ Over de afbakening van zowel verbintenissen ten opzichte van andere rechtsplichten als gebrekkige prestaties ten opzichte van andere vormen van niet-nakoming is in de context van andere rechtsregels al uitvoerig nagedacht. Dit artikel berust op de gedachte dat dit betekenis kan hebben voor het toepassingsbereik van de klachtplicht.

De opbouw van dit artikel is als volgt. Eerst recapituleer ik de rechtspraak van de Hoge Raad over het toepassingsbereik van de klachtplicht (par. 2). Daarna licht ik toe waarom mijns inziens de wetsgeschiedenis en de ratio van de klachtplicht als zodanig geen verder uitsluitsel geven over haar toepassingsbereik (par. 3). Vervolgens kom ik tot de kern: de begrippen 'verbintenis' (par. 4) en 'gebrekkige prestatie' (par. 5).

\section{De rechtspraak van de Hoge Raad}

De rechtspraak van de Hoge Raad over het toepassingsbereik van de klachtplicht laat zich vatten in drie thema's.

Ten eerste: de klachtplicht van art. 6:89 BW is van toepassing op verbintenissen (en niet op andere rechtsplichten). Het feit dat het artikel spreekt van een 'prestatie', een van de elementen van een verbintenis (zie par. 4.1), deed dat al vermoeden. Bovendien is art. 6:89 BW opgenomen in afdeling 9 ('De gevolgen van het niet nakomen van een verbintenis'). In 2013 heeft de Hoge Raad het ook uitdrukkelijk bevestigd: 'Art. 6:89 $\mathrm{BW}$ is van toepassing op alle verbintenissen, waaronder ook

9. Vranken 2019, p. 226.

10. Zie bijv. Asser/Scholten Algemeen deel* 1974, p. 48.

11. HR 8 februari 2013, ECLI:NL:HR:2013:BY4600 (Van de Steeg/Rabobank), r.o. 4.2.1.

12. HR 13 juli 2018, ECLI:NL:HR:2018:1176, r.o. 3.6. die uit beleggingsadviesrelaties.' ${ }^{13}$ In dat arrest paste de Hoge Raad de klachtplicht toe op de bancaire zorgplicht die voortvloeide uit een beleggingsadviesrelatie met particuliere beleggers, waarmee hij impliciet te kennen gaf die zorgplicht te rekenen onder de verbintenissen.

De klachtplicht is niet van toepassing op andere rechtsplichten dan verbintenissen. Zo is zij niet van toepassing op het opstellen en toezenden van een factuur. ${ }^{14}$ En, zoals hiervoor aangestipt, in 2018 oordeelde de Hoge Raad dat de klachtplicht niet ziet op een onrechtmatige daad. ${ }^{15}$ Die bestaat immers niet in de niet-nakoming van een verbintenis, maar in de schending van een andere rechtsplicht. Voor de goede orde: de klachtplicht is dus niet van toepassing op de onrechtmatige daad zelf, maar wel op de gebrekkige nakoming van de verbintenis tot schadevergoeding die daaruit voortvloeit.

Ten tweede: de klachtplicht ziet slechts op gebrekkige of ondeugdelijke prestaties (en niet op andere vormen van nietnakoming). Dat volgt reeds uit de bewoordingen van art. 6:89 BW en is ook door de Hoge Raad in 2007 bevestigd: '[A]rt. 6:89 BW [ziet] slechts op gevallen van ondeugdelijke nakoming en niet (mede) op gevallen waarin in het geheel geen prestatie is verricht.' 16

Dat een prestatie onherstelbaar gebrekkig is, doet niet ter zake. In 2017 boog de Hoge Raad zich over een geval waarin sprake was van de schending van een voortdurende inspanningsverplichting waarvan de nakoming voor het verleden blijvend onmogelijk was. Hij oordeelde:

'[D] e klachtplicht [is] ook van toepassing op overeenkomsten die een voortdurende verplichting behelzen en evenzeer in die gevallen waarin ook het gestelde tekortschieten een voortdurend karakter heeft. (...) ook ingeval een tekortkoming voor het verleden niet meer kan worden hersteld, [kan] de schuldenaar er belang bij hebben binnen bekwame tijd duidelijkheid te krijgen over het oordeel van de schuldeiser met betrekking tot de deugdelijkheid van zijn prestatie (...).'17

Ten derde: de klachtplicht treft alle rechtsvorderingen en verweren die feitelijk zijn gegrond op het gebrek in de prestatie. Het zijn dus niet alleen de vordering uit wanprestatie en de vordering tot ontbinding die sneuvelen als de schuldeiser te

13. HR 8 februari 2013, ECLI:NL:HR:2013:BY4600 (Van de Steeg/Rabobank), r.o. 4.2.1.

14. HR 11 mei 2001, ECLI:NL:HR:2001:AB1565 (Luttikhuis/Ridgefield), r.o. 3.3.

15. HR 13 juli 2018, ECLI:NL:HR:2018:1176, r.o. 3.6.

16. HR 23 maart 2007, ECLI:NL:HR:2007:AZ3531 (Brocacef/Simons), r.o. 4.3. Vgl. HR 13 juli 2018, ECLI:NL:HR:2018:1176, r.o. 3.6: 'De klachtplicht van art. 6:89 BW heeft, evenals die van art. 7:23 lid 1 BW bij een koopovereenkomst, betrekking op gebrekkige prestaties, dat wil zeggen prestaties van een schuldenaar (bij art. 7:23 BW: prestaties van een verkoper) die niet aan de verbintenis beantwoorden.'

17. HR 7 juli 2017, ECLI:NL:HR:2017:1270 (Nanada/Golden Earring), r.o. 6.2.1-6.2.2. 
laat klaagt. De Hoge Raad heeft beslist dat hetzelfde geldt voor de vordering en verweren uit onrechtmatige daad, ${ }^{18}$ dwaling ${ }^{19}$ en bedrog, ${ }^{20}$ indien die zijn gegrond op feiten die tevens de stelling zouden rechtvaardigen dat de prestatie niet aan de verbintenis beantwoordt. Anders zou de schuldeiser immers de klachtplicht kunnen omzeilen door zijn vordering creatief in te steken, bijvoorbeeld door vernietiging wegens dwaling te vorderen in plaats van ontbinding wegens tekortkoming. Met name de vraag of de klachtplicht van toepassing is bij bedrog, heeft veel pennen in beweging gebracht. ${ }^{21}$ In dit artikel laat ik dit derde thema verder rusten.

Kortom, de Hoge Raad heeft de piketpalen geslagen: de klachtplicht is van toepassing op alle verbintenissen, maar dan wel alleen bij gebrekkige prestaties, en de schuldeiser kan de klachtplicht niet omzeilen door voor een ander anker te gaan liggen. In de inleiding van dit artikel signaleerde ik echter al enkele openstaande vragen. Zo is onduidelijk of de klachtplicht van toepassing is op de betaling van geld, bijvoorbeeld van loon of overwerk. ${ }^{22}$ Hieronder illustreer ik dat het antwoord op die vragen niet volgt uit de wetsgeschiedenis of de ratio van de klachtplicht.

\section{Tweemaal een dood spoor}

\subsection{Wat zegt de wetsgeschiedenis?}

Wat zegt de wetsgeschiedenis over het toepassingsbereik van de klachtplicht? ${ }^{23}$ Bar weinig:

'Dit artikel berust op de gedachte dat een schuldenaar er op moet kunnen rekenen, dat de schuldeiser met bekwame spoed onderzoekt of de prestatie aan de verbintenis beantwoordt en dat deze, indien dit niet het geval blijkt te zijn, zulks, eveneens met spoed, aan de schuldenaar mededeelt. (...) Door het onderzoek, onderscheidenlijk de mededeling aan de schuldenaar, achterwege te laten, beneemt de schuldeiser zich het recht om over de gebreken van de prestatie te klagen. In het thans geldende wetboek is dit beginsel alleen voor de verborgen gebreken bij specieskoop

18. HR 23 november 2007, ECLI:NL:HR:2007:BB3733 (Ploum/Smeets), r.o. 4.8.2; HR 17 november 2017, ECLI:NL:HR:2017:2902 (MBS/ Prowi), r.o. 3.3.2; HR 13 juli 2018, ECLI:NL:HR:2018:1176, r.o. 3.6.

19. HR 26 juni 2007, ECLI:NL:HR:2007:AZ7617 (Pouw/Visser), r.o. 3.8.

20. HR 17 november 2017, ECLI:NL:HR:2017:2902 (MBS/Prowi), r.o. 3.3.3.

21. Zie bijv. H.N. Schelhaas, Klagen over bedrog!, NTBR 2013/6, afl. 2 , p. 53-54 (bevestigend); A.G. Castermans \& R. de Graaff, Samenloop van verjaringsregels bij bedrog, onrechtmatige daad en non-conformiteit, WPNR 2016, afl. 7119, p. 695-696 (genuanceerd); Jac. Hijma, Klachtplicht en bedrog, WPNR 2009, afl. 6781, p. 18-21 (ontkennend); J.J. Verhoeven, De koper bedrogen. Over oude rechtsvragen en wijsheden die voorbijgaan, NTBR 2010/21, afl. 5, p. 155-169 (ontkennend).

22. Gerrits \& Opdam 2017.

23. Zie voor een meer uitvoerige analyse van de wetsgeschiedenis W.L. Valk, Hoe verder met de klachtplicht?, NTBR 2014/2, afl. 1, p. 3-7. uitgesproken (artikel 1547 B.W.) De rechtspraak past het ook toe op de levering van soortzaken (...).24

Hiermee heb ik vrijwel de hele Toelichting-Meijers bij art. 6:89 BW geciteerd. Het is duidelijk dat de klachtplicht is geschreven voor gevallen waarin een prestatie gebrekkig is verricht (en niet voor gevallen waarin de prestatie niet of niet tijdig is verricht), maar veel meer valt uit de toelichting niet af te leiden. De wetgever heeft het 'beginsel' van tijdig klagen klaarblijkelijk een ruimer toepassingsbereik willen geven dan onder het oude recht, maar hoe ruim zegt hij niet. Het is bijvoorbeeld gissen of de wetgever mede het oog heeft gehad op de betaling van geld of op de nakoming van zorgplichten.

Latere parlementaire stukken over de klachtplicht gaan kort in op de inspectie na aflevering van zaken. ${ }^{25}$ Volgens sommige auteurs lijkt de wetgever daarom slechts te hebben gedacht aan stoffelijke prestaties en aan 'pekingeendengevallen'. ${ }^{26} \mathrm{Nu}$ de wetsgeschiedenis zo summier is, vind ik het lastig om veel betekenis toe te kennen aan het ontbreken van andere voorbeelden van prestaties dan de aflevering van een zaak. Ook ik vermoed dat de wetgever de implicaties van art. 6:89 BW heeft onderschat. Maar speculaties over de bedoeling van de wetgever kunnen lastig doorslaggevend zijn. De slotsom is dat de wetsgeschiedenis geen verder uitsluitsel geeft over het toepassingsbereik van de klachtplicht.

\subsection{Wat volgt uit de ratio van de klachtplicht?}

De ratio van de klachtplicht zegt in mijn ogen even weinig. De klachtplicht heeft twee doelen. ${ }^{27}$ Ten eerste behoedt de klachtplicht de schuldenaar voor bewijsproblemen. 'De bepaling van lid 1 beschermt de verkoper tegen late en daardoor moeilijk te betwisten klachten', aldus de Toelichting-Meijers bij art. 7:23 BW. ${ }^{28}$ Ten tweede beschermt de klachtplicht de schuldenaar tegen vorderingen waarop hij zich, gezien het tijdsverloop, niet meer in hoefde te stellen. ${ }^{29}$ Kort gezegd, de klachtplicht beschermt de schuldenaar tegen ongegronde en tegen onverwachte vorderingen.

24. C.J. van Zeben, J.W. du Pon \& M.M. Olthof (red.), Parlementaire geschiedenis van het nieuwe Burgerlijk Wetboek. Boek 6. Algemeen gedeelte van het verbintenissenrecht, Deventer: Kluwer 1981, p. 316-317.

25. Van Zeben, Du Pon \& Olthof (red.), Parl. Gesch. BW Boek 6, 1981, p. 317.

26. Smeehuijzen 2013, p. 745; Rijsterborgh \& Veldhoen 2015, p. 100.

27. Vgl. Tjittes 2013/31; Smeehuijzen 2013, p. 746; Caris \& Dulk 2018, p. 250; Valk 2014.

28. W.H.M. Reehuis, E.E. Slob \& C.J. van Zeben (red.), Parlementaire geschiedenis van het nieuwe Burgerlijk Wetboek, Invoering Boeken 3, 5 en 6. Boek 7. Bijzondere overeenkomsten, titels 1, 7, 9 en 14, Deventer: Kluwer 1991, p. 146.

29. Van Zeben, Du Pon \& Olthof (red.), Parl. Gesch. BW Boek 6, 1981, p. 316: 'Dit artikel berust op de gedachte dat een schuldenaar er op moet kunnen rekenen, dat de schuldeiser met bekwame spoed onderzoekt of de prestatie aan de verbintenis beantwoordt en dat deze, indien dit niet het geval blijkt te zijn, zulks, eveneens met spoed, aan de schuldenaar mededeelt.' Vgl. HR 8 februari 2013, ECLI:NL:HR:2013:BY4600 (Van de Steeg/Rabobank), r.o. 4.2.6. 


\section{Maandblad}

De klachtplicht heeft deze doelen gemeen met de leerstukken rechtsverwerking en bevrijdende verjaring. Rechtsverwerking en de klachtplicht beschermen de schuldenaar concreet, door na te gaan of de schuldenaar door het tijdstip van de klacht daadwerkelijk in zijn belangen is geschaad. Rechtsverwerking vereist dat bij de schuldenaar gerechtvaardigd vertrouwen is gewekt dat de schuldeiser zijn aanspraak niet meer geldend zal maken, of dat de positie van de schuldenaar onredelijk verzwaard of benadeeld zou worden indien de aanspraak alsnog geldend wordt gemaakt. ${ }^{30}$ De klachtplicht, aldus de Hoge Raad, moet worden gezien als een specifieke, in de wet geregelde vorm van rechtsverwerking. ${ }^{31}$ Verjaring abstrabeert deels van de omstandigheden van het geval. Het is in beginsel niet van belang of de schuldenaar in zijn belangen is geschaad. De termijn waarbinnen de schuldeiser moet ageren, is gefixeerd op doorgaans vijf jaar nadat hij daadwerkelijk in staat is te ageren. De ratio is echter dezelfde: bescherming van de schuldenaar tegen ongegronde (door bewijsproblemen moeilijk te betwisten) vorderingen en tegen onverwachte vorderingen. ${ }^{32}$

Deze ratio is mijns inziens te algemeen om iets te zeggen over het toepassingsbereik van de klachtplicht. Het is tekenend dat rechtsgeleerde schrijvers met een beroep op de ratio van de klachtplicht tot tegengestelde conclusies komen. Enerzijds zijn er schrijvers die de klachtplicht zouden willen reserveren voor gevallen waarin die ratio in het bijzonder opgaat. Bijvoorbeeld 'pekingeendengevallen', waarin naar analogie van het Pekingeenden-arrest de schuldeiser zijn 'momentum' mist (de eenden werden bij aflevering gekeurd en korte tijd daarna 'verwerkt'; toen de verkoper achteraf klaagde over toegepaste kortingen ter zake van 'vuile, kale en niet nuchtere eenden' was dat te laat). ${ }^{33}$ Anderzijds zijn er schrijvers die uit de ratio van de klachtplicht afleiden dat de klachtplicht juist een ruim toepassingsbereik zou moeten hebben. Ook bij een zuivere onrechtmatige daad moet de aangesproken partij bijvoorbeeld worden beschermd tegen de verslechtering van haar positie als gevolg van tijdsverloop. ${ }^{34}$ Rechtsverwerking en bevrijdende verjaring doen dat ook. Waarom de klachtplicht niet? Zo kan het dat voor- én tegenstanders van toepassing van de klachtplicht bij interne bestuurdersaansprakelijkheid zich op de ratio van de klachtplicht beroepen. ${ }^{35}$

30. HR 29 september 1995, ECLI:NL:HR:1995:ZC1827, NJ 1996/89 (Van den Bos/Provincial), r.o. 3.3; HR 11 november 2016, ECLI:NL:HR:2016:2574 (Bab/Cordial c.s. en MHS), r.o. 4.2.

31. HR 12 december 2014, ECLI:NL:HR:2014:3593 (FAR/Edco), r.o. 5.6.

32. Deze dubbele ratio gaat terug op het monumentale werk van Karl Spiro, Die Begrenzung privater Rechte durch Verjährungs-, Verwirkungs- und Fatalfisten, Bern: Stämpfli 1975, waarin hij als voornaamste doelen van de verjaring onderscheidt de 'Schutz vor unberechtigten Ansprüchen' en de 'Schutz gegen Überraschungen und Befürchtungen'; zie nr. 3-9; vgl. nr. 393. Spiro heeft in Nederland navolging gevonden bij W.L. Valk, Rechtsverwerking in drievoud (diss. Leiden), Deventer: Kluwer 1993, p. 72-73; J.L. Smeehuijzen, De bevrijdende verjaring (diss. Amsterdam VU), Deventer: Kluwer 2008, p. 24-32.

33. In deze lijn bijv. Smeehuijzen 2013; Rijsterborgh \& Veldhoen 2015, p. 100.

34. Zie bijv. Van Emden \& De Haan 2013.

35. Caris \& Kulk 2018, p. 250; Rijsterborgh \& Veldhoen 2015, p. 100.
Daarom in dit artikel een poging om het toepassingsbereik van de klachtplicht meer rechtssystematisch te benaderen.

\section{De verbintenis}

\subsection{Inleidende opmerkingen}

De klachtplicht is van toepassing op alle 'verbintenissen'. Voor het toepassingsbereik van de klachtplicht is dus van belang wat een verbintenis is en wat de verbintenis onderscheidt van andere rechtsplichten, waarop de klachtplicht niet van toepassing is.

Een verbintenis is, volgens de gebruikelijke definitie, een vermogensrechtelijke rechtsbetrekking tussen twee of meer personen, krachtens welke de een jegens de ander verplicht is tot een prestatie, waartoe de ander gerechtigd is. ${ }^{36}$

Verbintenissen ontstaan slechts indien dit uit de wet voortvloeit (art. 6:1 BW). De belangrijkste bron van verbintenissen is de overeenkomst (art. 6:248 BW). De klachtplicht is echter van toepassing op alle verbintenissen. Dus bijvoorbeeld ook op verbintenissen tot schadevergoeding wegens onrechtmatige daad (art. 6:162 BW), wanprestatie (art. 6:74 BW) en ongerechtvaardigde verrijking (art. 6:212 BW), verbintenissen uit hoofde van zaakwaarneming (art. 6:199-200 BW) en onverschuldigde betaling (art. 6:203 BW), ongedaanmakingsverbintenissen na ontbinding (art. 6:271 BW) en verbintenissen uit hoofde van een rechterlijke veroordeling tot betaling van een dwangsom of proceskosten. ${ }^{37}$ Voor een groot deel zijn dit verbintenissen tot betaling van een geldsom. Ik kom nog terug op de vraag in hoeverre de klachtplicht daarop ziet (zie par. 5.4). Maar dat geldt bijvoorbeeld niet voor een verbintenis tot teruggave van onverschuldigd ontvangen goederen en verbintenissen tot schadevergoeding in natura. Daarop is de klachtplicht zonder meer van toepassing.

Wat onderscheidt de verbintenis van andere rechtsplichten? Ten eerste is de verbintenis een vermogensrechtelijke rechtsbetrekking. Zuiver familierechtelijke of vennootschappelijke rechtsbetrekkingen zijn dus geen verbintenissen, zoals de verplichting van echtgenoten tot wederkerige getrouwheid, hulp en bijstand (art. 1:81 BW). De klachtplicht is op dergelijke verplichtingen niet van toepassing.

Ten tweede is de verbintenis concreet en tweezijdig. Concreet, omdat het gaat om een rechtsbetrekking tussen bepaalde personen. Tweezijdig, omdat tegenover de verplichting van de schuldenaar tot de prestatie een corresponderend recht op nakoming van de schuldeiser staat. Dat onderscheidt de ver-

36. Asser/Sieburgh 6-I 2016/6; J. Eggens, De bronnen van verbintenis, WPNR 1950, afl. 4158, p. 441; J.M. Smits, Bronnen van verbintenissen (Mon. NBW nr. A2), Deventer: Kluwer 2003, p. 6. Het begrip 'verbintenis' wordt gebruikt voor zowel de rechtsbetrekking (verbintenis in ruime zin) als de rechtsplicht die daar onderdeel van uitmaakt (verbintenis in enge zin). Een scherp onderscheid acht ik hier niet nodig.

37. Zie Asser/Sieburgh 6-I 2016/53-54b voor een overzicht van rechtsfeiten die verbintenissen doen ontstaan. 
bintenis van algemene ${ }^{38}$ of 'kale'39 vermogensrechtelijke rechtsplichten ${ }^{40}$ die gelden jegens eenieder en waarbij een corresponderend vorderingsrecht ontbreekt. Denk aan de verplichting om in het verkeer rechts te houden of de algemene verplichting om niet in strijd te handelen met de maatschappelijke zorgvuldigheidsnorm. Ook op dergelijke verplichtingen is de klachtplicht niet van toepassing.

De wetgever zag hierin aanleiding om een fundamenteel onderscheid te maken tussen de niet-nakoming van verbintenissen en de schending van andere rechtsplichten. Het eerste wordt aangemerkt als wanprestatie, het tweede als een onrechtmatige daad.

Bij dit onderscheid sta ik wat uitvoeriger stil. Veel vragen over het toepassingsbereik van de klachtplicht zijn namelijk terug te voeren op de vraag of er sprake is van de niet-nakoming van een verbintenis of van de schending van een andere rechtsplicht. En hoewel over de definitie van de verbintenis weinig discussie is, ligt dit onderscheid onder vuur. Hieronder bespreek ik de belangrijkste opvattingen.

\subsection{De verbintenis volgens Meijers en de wetgever}

In zijn boek De algemene begrippen van het burgerlijk recht benadrukt Meijers twee kenmerken van de verbintenis. Ten eerste levert het recht van de schuldeiser op nakoming een 'bijzonder subjectief recht' op. ${ }^{41}$

De eis van een bijzonder subjectief recht is weliswaar niet in het $\mathrm{BW}$ neergelegd, ${ }^{42}$ maar ligt er volgens de wetsgeschiedenis wel aan ten grondslag:

'Het ontwerp neemt als uitgangspunt, dat alleen bij die rechtsplichten, waarmee een subjectief vermogensrecht correspondeert van degene jegens wie de rechtsplicht bestaat, wordt gesproken van verbintenissen. $\mathrm{Bij}$ een verbintenis staat tegenover de rechtsplicht van de één een vorderingsrecht van de ander, dat een bestanddeel van diens vermogen is, en in het algemeen overdraagbaar en executabel is. (...) Zo kan bij de, uit de jurisprudentie van de Hoge Raad met betrekking tot artikel 1401 B.W. bekende, wettelijke rechtsplichten en betamelijkheidsplichten niet van verbintenissen gesproken worden, omdat met deze rechtsplichten niet een subjectief vermogensrecht van de door de norm beschermde persoon correspondeert. ${ }^{33}$

38. Aldus bijv. Asser/Sieburgh 6-I 2016/8.

39. Aldus bijv. Jac. Hijma \& M.M. Olthof, Compendium van het Nederlands vermogensrecht, Deventer: Wolters Kluwer 2017, nr. 299.

40. Met 'rechtsplichten' doel ik in het vervolg van dit artikel op vermogensrechtelijke rechtsplichten.

41. E.M. Meijers, De algemene begrippen van het burgerlijk recht, Leiden: Universitaire Pers Leiden 1948, p. 304.

42. De wetgever heeft de definitie van de verbintenis uitdrukkelijk aan de rechtswetenschap overgelaten. Zie Van Zeben, Du Pon \& Olthof (red.), Parl. Gesch. BW Boek 6, 1981, p. 37 (Inleidende opmerkingen).

43. Van Zeben, Du Pon \& Olthof (red.), Parl. Gesch. BW Boek 6, 1981, p. 38 (Inleidende opmerkingen).
Om te kunnen spreken van een verbintenis zou het recht van de schuldeiser op nakoming een subjectief vermogensrecht moeten opleveren. Wat is een subjectief vermogensrecht? Art. 3:6 BW noemt drie categorieën: rechten die overdraagbaar zijn, rechten die ertoe strekken de rechthebbende stoffelijk voordeel te verschaffen en rechten die verkregen zijn in ruil voor stoffelijk voordeel. Deze opsomming is niet-limitatief, ${ }^{44}$ maar het kennelijke uitgangspunt is dat aan het recht een zekere stoffelijke waarde kan worden toegekend. ${ }^{45}$

Ten tweede, aldus Meijers, moet de verplichting van de schuldenaar 'niet een algemene zijn, maar aan bijzondere feiten zijn ontstaan danken'. ${ }^{46}$ Algemene rechtsplichten, zoals verkeersregels en betamelijkheidsplichten, gelden jegens eenieder. Verbintenissen zouden zich hiervan onderscheiden doordat zij een rechtsbetrekking vestigen tussen twee of meer bepaalde personen. ${ }^{47}$ Met name dit zou het verschil in behandeling, het verschil tussen wanprestatie en onrechtmatige daad, moeten verklaren.

\subsection{De verbintenis volgens Eggens}

Eggens heeft dat bestreden. Kort gezegd komt Eggens' kritiek erop neer dat er weliswaar algemene rechtsplichten zijn, maar dat uit die rechtsplichten een verbintenis wordt 'geboren' op het moment dat de rechtsverhouding zich concretiseert, zodat elke onrechtmatige daad uiteindelijk bestaat in de niet-nakoming van een verbintenis. Eggens schreef:

'[A] an een onrechtmatig nalaten gaat, logisch en naar den tijd genomen, de concrete verplichting tot handelen vooraf, dus de verbintenis in den meest stricten zin, welker niet-nakoming eerst het onrechtmatigheids-moment schept, dat dus evenzeer wanpraestatie genoemd mag worden.' 48

Eggens heeft dit levendig geillustreerd aan de hand van de beruchte zaak van de Zutphense waterleiding. ${ }^{49}$ In een Zutphens pakhuis was 's nachts ten gevolge van de strenge vorst een waterleiding gesprongen. Terwijl een stortvloed van water over het aldaar opgeslagen leer stroomde, poogde de eigenaar van het pakhuis vergeefs de daarboven wonende juffrouw te bewegen de hoofdkraan af te sluiten. De juffrouw weigerde pertinent: het waren maar praatjes om haar van haar nachtrust

44. C.J. van Zeben, J.W. du Pon \& M.M. Olthof (red.), Parlementaire geschiedenis van het nieuwe Burgerlijk Wetboek. Boek 3. Vermogensrecht in het algemeen, Deventer: Kluwer 1981, p. 91 (MvA II).

45. Zie ook J.M. van Dunné, Verbintenissenrecht. Deel 2. Onrechtmatige daad. Overige verbintenissen, Deventer: Kluwer 2001, p. 10-11.

46. Meijers 1948, p. 304.

47. Asser/Sieburgh 6-I 2016/8.

48. Eggens 1950 , p. 455. Voor een onrechtmatig handelen gaat deze redenering niet op. Volgens Eggens resulteert een onrechtmatig handelen desondanks in wanprestatie, omdat gelijktijdig met het onrechtmatigheidsmoment de verhouding zich concretiseert en een verbintenis om niet te doen ontstaat.

49. HR 10 juni 1910, W 1910/9038. Ik noem de zaak berucht omdat de Hoge Raad destijds oordeelde dat de juffrouw geen rechtsplicht (in de zin van een wettelijke plicht) had geschonden en daarom niet onrechtmatig had gehandeld. Lindenbaum/Cohen dateert van negen jaar later. 


\section{Maandblad}

te beroven. Pas twintig minuten later werd de kraan dichtgedraaid, maar het kwaad was reeds geschied: het kostbare leer was bedorven. In zo'n geval van onrechtmatig nalaten, aldus Eggens, aanvaarden we eigenlijk 'een rechtsplicht tot sluiting [van de kraan] van een bepaald persoon jegens een ander persoon, hetgeen niet anders is dan het aanvaarden van een "verbintenis om te doen". 50

Eggens' betoog laat zien dat het kunstmatig is om het onderscheid tussen wanprestatie en onrechtmatige daad uitsluitend te baseren op een vermeend verschil tussen concrete verbintenissen en algemene rechtsplichten. In beide gevallen is namelijk sprake van de niet-nakoming van een concrete verplichting jegens een ander. ${ }^{51}$

Wat dit precies betekent voor het onderscheid tussen wanprestatie en onrechtmatige daad gaat het bestek van deze bijdrage te buiten. ${ }^{52}$ Het zou ervoor kunnen pleiten om de regels voor wanprestatie en onrechtmatige daad in sommige gevallen meer te coördineren. Het betekent echter niet dat er geen andere redenen kunnen zijn om bijvoorbeeld contractuele en delictuele aansprakelijkheid verschillend te behandelen.

\subsection{De verbintenis volgens de Hoge Raad}

Misschien heeft Eggens niet helemaal voor dovemansoren gesproken. De Hoge Raad lijkt namelijk een middenweg te volgen. Enerzijds heeft de Hoge Raad toepassing van de klachtplicht op onrechtmatige daad, en daarmee Eggens' betoog in de meest radicale vorm, verworpen. Anderzijds lijkt het erop dat de Hoge Raad de eis van een subjectief vermogensrecht heeft laten vallen. De Hoge Raad schaart contractuele zorgplichten namelijk onder de verbintenissen, althans hij past voor verbintenissen geschreven bepalingen op deze zorgplichten toe.

Laat ik dat kort toelichten. Een werkgever moet de werkomgeving op zodanige wijze inrichten als redelijkerwijs nodig is om te voorkomen dat de werknemer in de uitoefening van zijn werkzaamheden schade lijdt (art. 7:658 lid 1 BW). Een opdrachtnemer moet de zorgvuldigheid in acht nemen die van een redelijk bekwaam en redelijk handelend vakgenoot mag worden verwacht (art. 7:401 BW). Deze en dergelijke contractuele zorgplichten zijn naar de opvatting van Meijers en de wetgever geen verbintenissen. Er ontbreekt immers een corresponderend subjectief vermogensrecht. Men kan het recht van de werknemer op, kort gezegd, een veilige werkomgeving

50. Eggens 1950, p. 455.

51. Aldus bijv. ook H.C.F. Schoordijk, Het algemeen gedeelte van het verbintenissenrecht naar het nieuw Burgerlijk Wetboek, Deventer: Kluwer 1979, p. 41; W.L. Valk, De eenheid van ons verbintenissenrecht, NJB 1995, p. 1086-1087; Van Dunné 2001, p. 12-13; vgl. H. Drion, Aansprakelijkheid voor andermans fouten in verband met de inhoud der verplichtingen (oratie Leiden), Den Haag: Martinus Nijhoff 1958, p. 8-9.

52. Daarover bijv. Drion 1958; Valk 1995. bezwaarlijk karakteriseren als een vermogensrecht. ${ }^{53}$ Het is immers niet vatbaar voor overdracht en vertegenwoordigt geen stoffelijke waarde.

Toch behandelt de Hoge Raad contractuele zorgplichten als verbintenissen. Zo past de Hoge Raad in zijn rechtspraak art. 6:76 BW - de ruime aansprakelijkheid voor hulppersonen bij de uitvoering van verbintenissen - toe op de zorgplicht van de werkgever:

'Al dezen [aan wie de werkgever de algemene zorg voor de veiligheid van zijn werknemers overlaat; JV] kunnen in zo'n situatie (...) worden aangemerkt als "hulppersonen" van de werkgever waarvan hij gebruik makt bij het nakomen van zijn verplichting om voor de veiligheid van zijn werknemers te zorgen, wat meebrengt dat hij voor hun tekortschieten in die zorg op gelijke wijze aansprakelijk is als voor eigen tekortschieten. ${ }^{54}$

Er is misschien geen sprake van een subjectief vermogensrecht, maar door de zorgplicht van de werkgever als verbintenis aan te merken doet de Hoge Raad recht aan de rechtsverhouding tussen de werkgever en de werknemer, die door de arbeidsovereenkomst is geconcretiseerd.

De Hoge Raad bekent misschien nog duidelijker kleur wanneer hij de klachtplicht van art. 6:89 BW toepast op de (contractuele) bancaire zorgplicht. Ook tegenover deze zorgplicht staat geen subjectief vermogensrecht. In 2013 verklaarde de Hoge Raad de klachtplicht echter van toepassing op 'alle verbintenissen', om die vervolgens toe te passen op de bancaire zorgplicht in een beleggingsadviesrelatie met particuliere beleggers. $^{55}$

\subsection{Betekenis voor de klachtplicht}

Wat betekent het voorgaande voor het toepassingsbereik van de klachtplicht? Ten eerste bevestigt het waarom de klachtplicht niet van toepassing is op een onrechtmatige daad. ${ }^{56}$ Sommige schrijvers hebben dat wel betoogd, maar die maakten geen onderscheid tussen de onrechtmatige daad zelf - de schending van een (algemene) rechtsplicht - en de verbintenis tot schadevergoeding die daaruit voortvloeit. ${ }^{57}$ De Hoge Raad heeft dat rechtgezet.

53. Aldus ook S.D. Lindenbergh, Arbeidsongevallen en beroepsziekten, Deventer: Wolters Kluwer 2016, nr. 10.

54. HR 1 juli 1993, ECLI:NL:HR:1993:ZC1027, NJ 1993/687 m.nt. P.A Stein en J.M.M. Maeijer (Power/Ardross), r.o. 3.4. Zie ook HR 18 september 1998, ECLI:NL:HR:1998:ZC2706, NJ 1999/45 (Van Doorn/ NBM), r.o. 3.8; HR 4 oktober 2002, ECLI:NL:HR:2002:AE4080, NJ 2002/557 (Excellent/Suares), r.o. 3.2

55. Vgl. B.T.M. van der Wiel, annotatie bij HR 8 februari 2013, ECLI:NL:HR:2013:BY4600, JOR 2013/106 (Van de Steeg/Rabobank), nr. 6-8.

56. Uiteraard tenzij de vordering is gegrond op feiten die tevens de stelling zouden rechtvaardigen dat de prestatie niet aan de verbintenis beantwoordt, zie par. 2.

57. Van Emden \& De Haan 2013; W.H. van Boom, annotatie bij HR 8 februari 2013, ECLI:NL:HR:2013:BY4600, AA 2013, p. 759 (Van de Steeg/Rabobank). 


\section{Maandblad \\ Vermogensrecht}

Ten tweede is de klachtplicht van toepassing op contractuele zorgplichten, ook al zijn die naar de opvatting van de wetgever strikt genomen geen verbintenissen. De Hoge Raad behandelt de zorgplicht van de werkgever en de (contractuele) bancaire zorgplicht als verbintenissen en doet zo recht aan de concrete rechtsverhouding tussen contractspartijen. Ik zie geen aanleiding om te veronderstellen dat de Hoge Raad anders zal omgaan met andere contractuele zorgplichten. De klachtplicht is dus niet alleen van toepassing op bancaire zorgplichten en de zorgplicht van de werkgever, ${ }^{58}$ maar ook op de zorgplicht van een goed opdrachtnemer in het algemeen (art. 7:401 BW) en daarmee bijvoorbeeld bij de beroepsaansprakelijkheid van advocaten, ${ }^{59}$ notarissen, ${ }^{60}$ belastingadviseurs ${ }^{61}$ en (register)accountants. ${ }^{62}$ Hetzelfde geldt voor de zorgplicht van een goed hulpverlener die voortvloeit uit de geneeskundige behandelingsovereenkomst (art. 7:453 BW) en dus voor de beroepsaansprakelijkheid van artsen en andere medische hulpverleners. ${ }^{63}$ Ten slotte wijs ik nog op de zorgplichten van de huurder (art. 7:213 BW), de bewaarnemer (art. 7:602 BW) en de bruiklener (art. 7A:1781 BW). Ook daarop is de klachtplicht van toepassing. ${ }^{64}$

Aangenomen moet worden dat de klachtplicht niet ziet op de schending van zuiver delictuele zorgplichten, ook die van een bank of notaris ten opzichte van derden. De Hoge Raad heeft toepassing op onrechtmatige daad immers duidelijk van de hand gewezen. ${ }^{65}$

\subsection{Interne bestuurdersaansprakelijkheid}

In de literatuur woedt een debat over de vraag of de klachtplicht van toepassing is op de interne bestuurdersaansprakelijkheid op grond van art. 2:9 BW, dat wil zeggen de aansprakelijkheid van de bestuurder jegens de vennootschap

58. Zie bijv. de rechtspraak genoemd in Gerrits \& Opdam 2017; Rb. Den Haag 5 december 2018, ECLI:NL:RBDHA:2018:16011, r.o. 4.3-4.6; Rb. Den Haag 15 mei 2019, ECLI:NL:RBDHA:2019:7370, r.o. 4.1-4.5.

59. Zie bijv. Hof Den Haag 17 december 2013, ECLI:NL:GHDHA: 2013:5389, r.o. 24-26; Hof Arnhem-Leeuwarden 25 juli 2017, ECLI:NL:GHARL:2017:6377, r.o. 4.5-4.7; Hof Den Haag 12 februari 2019, ECLI:NL:GHDHA:2019:157, r.o. 5.1-5.3.

60. Zie bijv. Hof Den Haag 23 september 2014, ECLI:NL:GHDHA: 2014:4503, r.o. 4.1-4.6; Hof Arnhem-Leeuwarden 22 januari 2019, ECLI:NL:GHARL:2019:536, r.o. 4.6-4.7.

61. Zie bijv. Hof 's-Hertogenbosch 30 december 2014, ECLI:NL:GHSHE: 2014:5664, r.o. 3.3-3.7.4; Hof Amsterdam 24 juni 2014, ECLI:NL:GHAMS:2014:3142, r.o. 3.8-3.10.

62. Zie bijv. Hof Amsterdam 10 november 2009, ECLI:NL:GHAMS 2009:BL8340, r.o. 4.1-4.11; Hof 's-Hertogenbosch 29 mei 2012, ECLI:NL:GHSHE:2012:BW7059, r.o. 4.6; Hof Arnhem-Leeuwarden 27 augustus 2019, ECLI:NL:GHARL:2019:6932, r.o. 3.8.

63. Zie bijv. Hof Den Haag 6 september 2016, ECLI:NL:GHDHA: 2016:2503, r.o. 4.7-4.8; Rb. Dordrecht 8 april 2009, ECLI:NL:RBDOR:2009:BI1216, r.o. 4.26 .

64. Zie bijv. Rb. Oost-Brabant 27 januari 2016, ECLI:NL:RBOBR: 2016:362, r.o. 4.2-4.3 (bewaargeving) en Rb. Zeeland-West-Brabant 21 juni 2017, ECLI:NL:RBZWB:2017:5561, r.o. 4.5 (bewaargeving/bruikleen).

65. In gevallen van samenloop waarbij de vordering is gegrond op feiten die tevens de stelling zouden rechtvaardigen dat sprake is van een gebrek in de nakoming van een contractuele zorgplicht, is de klachtplicht uiteraard wel van toepassing, zie par. 2 . wegens onbehoorlijk bestuur. ${ }^{66}$ Welke inzichten levert het voorgaande op?67

Om te beginnen moet deze aansprakelijkheid worden onderscheiden van de eventuele contractuele aansprakelijkheid van de bestuurder jegens de vennootschap als werknemer (art. 7:661 lid $1 \mathrm{BW}$ beperkt aansprakelijkheid jegens de werkgever tot gevallen van opzet of bewuste roekeloosheid) of, indien de bestuurder werkzaam is op grond van een managementovereenkomst, als goed opdrachtnemer (art. 7:401 BW). Het lijdt geen twijfel dat de klachtplicht van toepassing is op deze contractuele aansprakelijkheid, die bestaat in de niet-nakoming van verbintenissen. ${ }^{68} \mathrm{Het}$ is echter de vraag of dat ook geldt voor de aansprakelijkheid op grond van art. 2:9 BW. Is de verplichting van de bestuurder tegenover de vennootschap 'tot een behoorlijke vervulling van zijn taak' een verbintenis? Deze vraag is omstreden. ${ }^{69}$ Over de rechtsverhouding tussen bestuurder en vennootschap zijn boeken vol geschreven, en ik wil mij hier niet ten gronde in die discussie mengen. Ik veroorloof mij twee opmerkingen vanuit een rechtssystematisch perspectief.

De eerste vraag die moet worden gesteld, is of de verplichting van de bestuurder krachtens art. 2:9 BW (mede) voortvloeit uit een vermogensrechtelijke rechtsbetrekking. Alleen dan kan immers sprake zijn van een verbintenis. Zuiver vennootschappelijke rechtsbetrekkingen zijn geen verbintenissen. De vraag is dus of de verplichting van de bestuurder uitsluitend voortvloeit uit zijn vennootschappelijke band met de vennootschap, of (tevens) uit hun contractuele rechtsverhouding. De Hoge Raad lijkt in 2014 uit te gaan van het eerste:

' $[\mathrm{N}]$ aar Nederlands recht [wordt] onderscheid gemaakt tussen de aansprakelijkheid van een persoon in zijn hoedanigheid van bestuurder van een vennootschap (uit hoofde van schending van zijn vennootschapsrechtelijke verplichting tot behoorlijke taakvervulling krachtens art. 2:9 BW dan wel uit hoofde van onrechtmatig handelen in de zin van art. 6:162 BW) en de afgezien van deze hoedanigheid op die persoon rustende aansprakelijkheid als werknemer van die vennootschap (uit hoofde van opzet of bewuste roekeloosheid bij de uitvoering van zijn arbeidsovereenkomst als bedoeld in art. 7:661 BW). ${ }^{70}$

De Hoge Raad spreekt van een 'vennootschapsrechtelijke verplichting' en onderscheidt die van de verplichting van de

66. Zie noot 7 .

67. De bestuurdersaansprakelijkheid krachtens art. 2:138 en 2:248 BW wordt doorgaans aangemerkt als 'extern' (jegens de boedel of de gezamenlijke schuldeisers) en verschilt in zoverre niet van de aansprakelijkheid uit onrechtmatige daad. Indien deze aansprakelijkheid zou worden aangemerkt als 'intern' (jegens de vennootschap), is mijn analyse ten aanzien van art. 2:9 BW mutatis mutandis van toepassing.

68. Aldus ook Schild 2016, p. 63; Tjittes 2017, p. 480.

69. Voor een overzicht, zie Tjittes 2017, p. 481-482.

70. HR 24 januari 2014, ECLI:NL:HR:2014:164 (Holterman c.s./Spies), r.o. 3.8.2. 


\section{Maandblad}

bestuurder als werknemer. Ik ben dan ook geneigd om aan te nemen dat de verplichting tot behoorlijke taakvervulling krachtens art. 2:9 BW niet voortvloeit uit een vermogensrechtelijke rechtsbetrekking. ${ }^{71}$ Dat betekent dat geen sprake is van een verbintenis, zodat de klachtplicht toepassing mist.

Als toch sprake zou zijn van een vermogensrechtelijke rechtsbetrekking omdat de verplichting tot behoorlijke taakvervulling (tevens) zou kwalificeren als een contractuele plicht, rijst een tweede vraag: zou art. 2:9 lid $1 \mathrm{BW}$ in dat geval een verbintenis inhouden of een andere (vermogensrechtelijke) rechtsplicht? In dat geval zou ik willen aannemen dat sprake is van een verbintenis. Niet valt dan immers in te zien wat de verplichting tot behoorlijke taakvervulling onderscheidt van (andere) contractuele zorgplichten, zoals de zorgplicht van de werkgever. ${ }^{72}$ Maar, zoals gezegd, ik ben geneigd aan te nemen dat toepassing van de klachtplicht op art. 2:9 BW strandt op de eerste stap: de verplichting tot behoorlijke taakvervulling is niet vermogensrechtelijk van aard en dus geen verbintenis.

\section{De gebrekkige prestatie}

\subsection{Inleiding}

De klachtplicht is van toepassing op alle verbintenissen, maar ziet slechts op 'gebrekkige prestaties' ofwel 'gevallen van ondeugdelijke nakoming, aldus de Hoge Raad (zie par. 2). Voor het toepassingsbereik van de klachtplicht is dus van belang wanneer sprake is van ondeugdelijke nakoming en wat ondeugdelijke nakoming onderscheidt van andere vormen van niet-nakoming.

Over deze vragen is vóór het NBW nagedacht. Onder het oude recht werd namelijk onderscheid gemaakt tussen drie vormen van niet-nakoming voor de vraag of voor het intreden van verzuim een ingebrekestelling was vereist: (1) niet-tijdige nakoming, (2) niet-behoorlijke of ondeugdelijke nakoming, en (3) (onontkoombare of algehele) niet-nakoming. ${ }^{73}$ De hoofdregel was dat ondeugdelijke nakoming en niet-nakoming verzuim van rechtswege deden intreden, terwijl daarvoor bij niettijdige nakoming een ingebrekestelling nodig was. De eisen van de goede trouw konden echter meebrengen dat ook in een

71. Aldus bijv. ook Rijsterborgh \& Veldhoen 2015, p. 101-102; Schild 2016, p. 63; B.F. Assink, Slagter. Compendium ondernemingsrecht (deel 1), Deventer: Kluwer 2013, p. 877. Vgl. Hof Arnhem-Leeuwarden 24 januari 2017, ECLI:NL:GHARL:2017:523, r.o. 5.14.

72. De eis van een corresponderend subjectief vermogensrecht wordt dan ook ten onrechte gesteld door Hof Arnhem-Leeuwarden 24 januari 2017, ECLI:NL:GHARL:2017:523, r.o. 5.14 en Rb. Zeeland-West-Brabant 5 november 2014, ECLI:NL:RBZWB:2014:9203, r.o. 3.14.

73. Asser/Rutten 4-I 1981, p. 166-167; H. Drion, Jac. Hijma \& M.M. Olthof, Compendium van het Nederlands vermogensrecht, Deventer: Kluwer 1991, p. 184-186; M.H. Wissink, Wanprestatie en ingebrekestelling, in: A.R. Bloembergen \& W.M. Kleijn (red.), Contractenrecht V, Deventer: Kluwer, aant. 675-684 (losbladig, afgesloten in 1992); vgl. S.N. van Opstall, Hofmann. Het Nederlandse verbintenissenrecht. Deel 1, eerste gedeelte, Groningen: H.D. Tjeenk Willink 1976, p. $91-124$. geval van ondeugdelijke nakoming voor het intreden van verzuim ingebrekestelling was vereist. ${ }^{74}$

Dit traditionele onderscheid lijkt terug te keren in de rechtspraak van de Hoge Raad over het toepassingsbereik van de klachtplicht: '[A]rt. 6:89 BW [ziet] slechts op gevallen van ondeugdelijke nakoming en niet (mede) op gevallen waarin in het geheel geen prestatie is verricht. ${ }^{75}$ Reden om wat uitvoeriger bij dit onderscheid stil te staan.

\subsection{Niet-tijdige nakoming, niet-behoorlijke nakoming en niet-nakoming}

Men spreekt van niet-tijdige nakoming als de schuldenaar na het overeengekomen tijdstip nog niet heeft gepresteerd, maar de prestatie nog mogelijk is. ${ }^{76}$ De tekortkoming bestaat dus uitsluitend in een vertraging in de nakoming van de verbintenis.

Men spreekt van niet-behoorlijke of ondeugdelijke nakoming als de schuldenaar weliswaar heeft gepresteerd, maar die prestatie in meer of mindere mate tekortschiet. ${ }^{77}$ De schuldenaar verricht bijvoorbeeld een andere prestatie dan overeengekomen, presteert niet volledig, of levert een prestatie die niet voldoet aan de afgesproken kwaliteitsnormen. ${ }^{78}$

(Onontkoombare of algehele) niet-nakoming betreft ten slotte de gevallen waarin nakoming onmogelijk of redelijkerwijs niet meer te verwachten is. ${ }^{79}$ De belangrijkste voorbeelden uit de literatuur:

1. Nakoming was slechts mogelijk binnen een zekere termijn, die de schuldenaar heeft laten voorbijgaan. ${ }^{80}$ Onvermijdelijk is het voorbeeld van de kleermaker die de bruidsjurk niet voor de bruiloft aflevert.

2. De schuldenaar heeft het zichzelf onmogelijk gemaakt om aan de verbintenis te voldoen, bijvoorbeeld door de te leveren specieszaak te vernietigen. ${ }^{81}$

3. De schuldenaar overtreedt een verbintenis om niet te doen, bijvoorbeeld een non-concurrentiebeding. ${ }^{82}$ Die overtreding kan immers niet ongedaan worden gemaakt.

4. De niet-tijdige of ondeugdelijke nakoming van een voortdurende verbintenis, zoals de verplichting van de verhuur-

74. HR 22 mei 1981, ECLI:NL:HR:1981:AG4192, NJ 1982/59 m.nt C.J.H. Brunner (Van der Gun/Farmex).

75. HR 23 maart 2007, ECLI:NL:HR:2007:AZ3531 (Brocacef/Simons), r.o. 4.3.

76. Asser/Rutten 4-I 1981, p. 167.

77. Vgl. HR 13 juli 2018, ECLI:NL:HR:2018:1176, r.o. 3.6: 'gebrekkige prestaties, dat wil zeggen prestaties van een schuldenaar (...) die niet aan de verbintenis beantwoorden'.

78. Asser/Rutten 4-I 1981, p. 167 en 173-175; Wissink, in: Contractenrecht $\mathrm{V}$, aant. 611-612.

79. Asser/Rutten 4-I 1981, p. 167.

80. Asser/Rutten 4-I 1981, p. 173; Wissink, in: Contractenrecht V, aant. 677; Drion, Hijma \& Olthof 1991, nr. 371; Hofmann/Van Opstall 1976, p. 110; vgl. Asser/Sieburgh 6-I 2016/383.

81. Asser/Rutten 4-I 1981, p. 174; Drion, Hijma \& Olthof 1991, nr. 371.

82. Asser/Rutten 4-I 1981, p. 174; Wissink, in: Contractenrecht V, aant. 676; Hofmann/Van Opstall 1976, p. 113-114; vgl. Asser/Sieburgh 6-I $2016 / 383$. 
der om de zaak ter beschikking van de huurder te stellen. ${ }^{83}$ Ook die niet-nakoming kan niet op een later moment ongedaan worden gemaakt: 'verloren tijd kan immers niet worden ingehaald'. ${ }^{4}$

5. De schuldenaar presteert onherstelbaar gebrekkig. ${ }^{85}$

\subsection{Betekenis voor de klachtplicht}

Kan dit traditionele onderscheid een-op-een worden vertaald naar de klachtplicht, in die zin dat uitsluitend de categorie 'ondeugdelijke nakoming' onder het toepassingsbereik van de klachtplicht valt? Grotendeels wel, maar niet een-op-een. Het onderscheid werd onder oud recht gemaakt voor de vraag of voor het intreden van verzuim een ingebrekestelling was vereist. Dat verklaart waarom gevallen van ondeugdelijke nakoming waarbij deugdelijke nakoming onmogelijk was of was geworden, onder de noemer '(onontkoombare) niet-nakoming' werden gebracht. In dergelijke gevallen heeft een ingebrekestelling geen zin. ${ }^{86}$ De klachtplicht ziet echter volgens de tekst van art. 6:89 BW op alle 'gebrekkige prestaties', ook de prestaties die onmogelijk zijn (geworden). De Hoge Raad heeft dat in 2017 bevestigd in een zaak over de schending van een voortdurende inspanningsverplichting (zie par. 2).

Afgezien van deze kanttekening geeft het onderscheid tussen niet-tijdige nakoming, ondeugdelijke nakoming en niet-nakoming inderdaad verder inzicht in het toepassingsbereik van de klachtplicht. ${ }^{87}$ Ten eerste ziet de klachtplicht niet op gevallen van niet tijdig nakomen. Over een vertraging in de nakoming hoeft dus niet te worden geklaagd. ${ }^{88}$

Ten tweede ziet de klachtplicht ook niet op gevallen van algehele niet-nakoming, waarin géén gebrekkige prestatie is verricht. Dat betreft dus de eerste drie voorbeelden die hierboven zijn genoemd. De klachtplicht is bijvoorbeeld niet van toepassing op de schending van een verbintenis om niet te doen, zo is ook meermaals bevestigd in lagere rechtspraak. ${ }^{89}$ In dat geval kan immers niet worden gezegd dat een prestatie is verricht. De klachtplicht is dus ook niet van toepassing op de overtreding van een non-concurrentiebeding. ${ }^{90}$

83. Wissink, in: Contractenrecht V, aant. 681a; Hofmann/Van Opstall 1976, p. 111-113; vgl. Asser/Sieburgh 6-I 2016/383.

84. Concl. A-G Biegman-Hartogh, ECLI:NL:PHR:1987:AG5548, voor HR 27 februari 1987, NJ 1987/987 m.nt. P.A. Stein, nr. 13.

85. Asser/Rutten 4-I 1981, p. 167; Hofmann/Van Opstall 1976, p. 109; vgl. Drion, Hijma \& Olthof 1991, nr. 371; vgl. Asser/Sieburgh 6-I 2016/383.

86. Onder huidig recht is verzuim daarom niet vereist voor zover nakoming reeds blijvend onmogelijk is.

87. Vgl. A-G Wissink in zijn conclusie voor HR 2 september 2011, ECLI:NL:PHR:2011:BQ3876, NJ 2012/75 m.nt. P. van Schilfgaarde (VDE/Fuchs), nr. 2.50.6-2.50.7.

88. Zie bijv. Hof 's-Hertogenbosch 23 augustus 2001, ECLI:NL:GHSHE: 2001:AD3875, r.o. 4.7 (niet-nakoming van de overeengekomen levertijden).

89. Zie bijv. Hof Amsterdam 10 april 2012, ECLI:NL:GHAMS: 2012:BX4332, r.o. 3.8 (verplichting om niet te saneren); Hof Leeuwarden 9 januari 2008, ECLI:NL:GHLEE:2008:BC1857, r.o. 9.1 (verplichting om niet te verhuren).

90. Zie bijv. Rb. Zeeland-West-Brabant 25 april 2018, ECLI:NL:RBZWB: 2018:2664, r.o. 4.2 .
Ten derde is de klachtplicht wél van toepassing op alle gevallen van ondeugdelijke nakoming, of die ondeugdelijke nakoming nu onherstelbaar is of niet. Overigens kan dit nog steeds leiden tot kwalificatievragen, zoals ik nu zal illustreren.

\subsection{Kwalificatie: gebrekkige prestatie of geheel geen prestatie?}

In de literatuur wordt er terecht op gewezen dat het onderscheid tussen niet-tijdige nakoming, ondeugdelijke nakoming en niet-nakoming niet altijd scherp valt te maken. ${ }^{91}$ Dat laat zich vooral voelen in gevallen van gedeeltelijke nakoming. ${ }^{92}$

Neem bijvoorbeeld een boekbinder die slechts vier van de vijf afgesproken boeken restaureert. Is hier sprake van ondeugdelijke nakoming omdat de boeken niet zijn gerestaureerd conform de afgesproken hoeveelheid, zodat de klachtplicht van toepassing is? Of moet ten aanzien van het niet-gerestaureerde boek worden gezegd dat (nog) in het geheel geen prestatie is verricht, zodat de klachtplicht toepassing mist?

Het antwoord op deze vragen moet mijns inziens worden verkregen door uitleg van de rechtsverhouding tussen de boekbinder en zijn schuldeiser. ${ }^{93}$ Leidt die uitleg tot de conclusie dat de boekbinder maar één prestatie moest verrichten, namelijk het restaureren van vijf boeken, dan is die prestatie ondeugdelijk nagekomen. ${ }^{94}$ Is de uitleg echter dat de boekbinder vijf prestaties moest verrichten, namelijk vijf keer het restaureren van een boek, dan is sprake van niet-nakoming van een van die prestaties.

Naarmate tussen de levering van verschillende goederen of diensten een nauwere samenhang bestaat, zal eerder sprake zijn van ondeugdelijke nakoming. ${ }^{95}$ Zo paste het gerechtshof Amsterdam de klachtplicht toe op een geval waarin een café minder hectoliters bier van de brouwerij had afgenomen dan afgesproken. ${ }^{96}$ In onze casus zou relevant kunnen zijn of het gaat om vijf boeken uit één serie die dezelfde behandeling moeten krijgen, of om vijf unieke boeken die elk hun eigen restauratietraject nodig hebben.

De discussie over de vraag of de klachtplicht van toepassing is op de betaling van geld, is terug te voeren op dezelfde kwalificatiekwestie. De klachtplicht is van toepassing op alle verbintenissen, en dus ook op verbintenissen tot betaling van een geldsom. De vraag die dus resteert, is of de betaling van een geldsom ondeugdelijk kan zijn. Ook daarover kan weinig twij-

91. Zie bijv. Asser/Rutten 4-I 1981, p. 167; vrijwel ongewijzigd overgenomen in Asser/Sieburgh 6-I 2016/381.

92. A-G Wissink in zijn conclusie voor HR 2 september 2011, ECLI:NL:PHR:2011:BQ3876, NJ 2012/75 m.nt. P. van Schilfgaarde (VDE/Fuchs), nr. 2.50.6.

93. Uitvoerig hierover Katan 2007, p. 45-48.

94. Dit is voor koop neergelegd in art. 7:17 lid 3 BW: er is sprake van nonconformiteit indien het afgeleverde in getal, maat of gewicht van het overeengekomene afwijkt.

95. Vgl. Katan 2007, p. 47.

96. Hof Amsterdam 29 januari 2013, ECLI:NL:GHAMS:2013:130, r.o. 3.5 . 
fel bestaan: de geldsom kan bijvoorbeeld zijn betaald in de verkeerde valuta, of wel aan de juiste persoon maar op het verkeerde rekeningnummer. Maar de hamvraag is natuurlijk: is ook de onvolledige betaling van een geldsom ondeugdelijk? Men zou kunnen betogen dat hier sprake is van niet (tijdig) nakomen van een deel. Als argument hiervoor wordt aangevoerd dat het gaat om een manco in kwantiteit, niet in kwaliteit. ${ }^{97}$ In deze gedachtegang wordt de betalingsverplichting - in theorie tot op de eurocent - opgesplitst in talloze kleine prestaties, waarvan een deel niet is nagekomen. Overtuigend acht ik dat niet. De rechtsverhouding zal doorgaans zo moeten worden uitgelegd dat partijen één prestatie zijn overeengekomen, namelijk de betaling van een zekere som geld. ${ }^{98}$ Bovendien levert volgens de wet ook een manco in kwantiteit non-conformiteit op (art. 7:17 lid $3 \mathrm{BW}$ ), waarop de klachtplicht van toepassing is (art. 7:23 lid $1 \mathrm{BW}$ ). De schuldenaar die een euro te weinig betaalt, presteert dan ook even gebrekkig als de verkoper die een zaak te weinig levert. Hoewel rechtspraak en literatuur over deze kwestie verdeeld zijn, ${ }^{99}$ past het dus in het systeem om de klachtplicht toe te passen op de onvolledige betaling van een geldsom. ${ }^{100}$

\section{Ter afsluiting}

Waar wetsgeschiedenis en ratio zo weinig richting geven, liggen gelegenheidsargumenten op de loer. Dit artikel is in de eerste plaats een pleidooi voor een meer systematische benadering van het toepassingsbereik van de klachtplicht. Wat levert die benadering op?

Ten eerste: de klachtplicht is van toepassing op alle verbintenissen. Dat zijn in de eerste plaats verbintenissen uit overeenkomst. De klachtplicht ziet ook op de schending van contractuele zorgplichten, zoals de bancaire zorgplicht, de zorgplicht van de werkgever en de contractuele zorgplichten van advocaten, notarissen, belastingadviseurs, accountants, artsen, huurders, bewaarnemers en bruikleners. De klachtplicht is echter ook van toepassing op andere verbintenissen dan die uit overeenkomst, bijvoorbeeld op verbintenissen tot schadevergoeding (wegens onrechtmatige daad) en ongedaanmakingsverbintenissen.

De klachtplicht ziet niet op de schending van andere rechtsplichten. De klachtplicht ziet dus niet op de (zuivere) onrechtmatige daad zelf. De klachtplicht ziet ook niet op de schending van zuiver delictuele zorgplichten, bijvoorbeeld van de notaris ten opzichte van derden.

97. Aldus met name A-G Wissink in zijn conclusie voor HR 2 september 2011, ECLI:NL:PHR:2011:BQ3876, NJ 2012/75 m.nt. P. van Schilfgaarde (VDE/Fuchs), nr. 2.50.7. Vgl. Asser/Hijma 7-I 2019/848.

98. Aldus ook Van Cassel-van Zeeland 2019, p. 286; Katan 2007, p. 47; vgl. Schild 2016, p. 64.

99. Zie noot 6 .

100. Dat wil overigens niet zeggen dat een beroep op de klachtplicht vaak zal opgaan. Bij een girale betaling is het belangrijkste bewijs niet aan achteruitgang onderhevig. De schuldenaar zal bij een late klacht dus niet snel in zijn belangen zijn geschaad.
Niet-vermogensrechtelijke rechtsbetrekkingen zijn geen verbintenissen. Ik ben daarom geneigd om aan te nemen dat de klachtplicht niet van toepassing is op de vennootschapsrechtelijke verplichting tot behoorlijke taakvervulling krachtens art. 2:9 BW (interne bestuurdersaansprakelijkheid).

Ten tweede: de klachtplicht ziet slechts op gebrekkige prestaties. Onder het oude recht werd, voor de vraag of voor het intreden van verzuim een ingebrekestelling was vereist, onderscheid gemaakt tussen niet-tijdige nakoming, ondeugdelijke nakoming en (algehele) niet-nakoming. Dit onderscheid heeft nu betekenis gekregen voor het toepassingsbereik van de klachtplicht. Gevallen van ondeugdelijke nakoming vallen onder de klachtplicht, of deugdelijke nakoming nog mogelijk is of niet. Dat betekent mijns inziens dat de klachtplicht ook ziet op de onvolledige nakoming van een verbintenis tot betaling van een geldsom.

De klachtplicht ziet niet op gevallen van niet-tijdige nakoming of algehele niet-nakoming, waarin in het geheel geen prestatie is verricht. De klachtplicht ziet dus niet op een vertraging in de nakoming. De klachtplicht ziet ook niet op de overtreding van verbintenissen om niet te doen, zoals een non-concurrentiebeding.

Is dit alles wenselijk? Daarover zijn de meningen verdeeld, met name omdat de klachtplicht als 'schuldenaarsvriendelijk' wordt ervaren en men allerlei praktische bezwaren ziet. Willen we het systeem van het recht geen geweld aandoen, dan moet de oplossing echter niet worden gezocht in het toepassingsbereik, maar in de toepassing van de klachtplicht. Haal daar de scherpe randjes - en dan denk ik aan de klachttermijn en de rechtsgevolgen - vanaf, ${ }^{101}$ dan is het toepassingsbereik van de klachtplicht zo'n netelige kwestie niet meer.

101. Voor enkele suggesties, zie Valk 2014; Vranken 2019 